OnLine Appendix

\title{
Male Social Status and Women's Work
}

Bernhardt, A., Field, E., Pande, R., Rigol, N., Schaner, S., and Troyer-Moore, C. 


\section{Table A1 Labor Intervention Activity Description}

\section{A. Description}

All sample women were recruited by a local landowner to work as a laborer for one day on their field. Landowners were compensated by the research team for the female respondents' wages and they were paid wages in line with local market rates. When women were invited to participate in the work intervention, they were not told that this was part of a research study. Surveyors measured attendance at the work intervention. Surveyors also visited all female respondents the following day. Respondents who did not attend the work intervention were asked: Why did you not work on [landowner's] field on [labor intervention date]?

B. Outcome Variable

Respondents who either attended the work intervention or responded the next-day survey question by saying, "I had an other work commitment" and who then reported non-zero wages for the other work commitment are considered as having worked.

Other response options were: Not allowed to work/ Have children to take care of/ Household chores take up my time/ Do not want to work/ Sickness or old age/ Personal differences with landowner/ Landowner is of lower caste/ No one was available to accompany me/ No one came to recruit me for work 


\section{Table A2 Questionnaire}

\begin{tabular}{|c|c|c|}
\hline Variable & Description & Answer \\
\hline \multicolumn{3}{|c|}{ A. Intra-Household Bargaining (Female Respondents Only) } \\
\hline Decision Employment & Who decides whether you take employment outside the household? & $\begin{array}{l}\text { 1. I mostly decide/ } 2 \text {. My husband mostly } \\
\text { decides / } 3 \text {. We consult each other and decide } \\
\text { together }\end{array}$ \\
\hline Travel to Market & When was the last time that you visited the market in the Panchayat? & Date \\
\hline Travel to Clinic Alone & $\begin{array}{l}\text { If there was an emergency and you had to go to the primary health center would } \\
\text { you be allowed to go alone? }\end{array}$ & Yes/No \\
\hline \multicolumn{3}{|c|}{ B. Household Preferences (Male and Female Respondents) } \\
\hline $\begin{array}{l}\text { Personal Opinion } \\
\text { about Women's Work }\end{array}$ & $\begin{array}{l}\text { People have different opinions about women going out to work. Some people feel } \\
\text { that women in your caste and village should not work outside the home to earn } \\
\text { money and they should only look after their families, while others say that there is } \\
\text { nothing wrong if women go out for work to earn money. What is your opinion? }\end{array}$ & $\begin{array}{l}\text { Women can not go out for work/ Women can } \\
\text { go out for work }\end{array}$ \\
\hline $\begin{array}{l}\text { Perception of Spouse } \\
\text { Personal Opinion } \\
\text { about Women's Work }\end{array}$ & What does your spouse think about this question? & $\begin{array}{l}\text { Women can not go out for work/ Women can } \\
\text { go out for work }\end{array}$ \\
\hline $\begin{array}{l}\text { Ranking Life Priori- } \\
\text { ties }\end{array}$ & $\begin{array}{l}\text { What is the most important to you in your life right now? [Pictures shown and } \\
\text { verbal description of: } 1 \text {. Financial stability, } 2 \text {. Community respect, } 3 \text {. Harmonious } \\
\text { relationship with spouse, } 4 \text {. Wife is obedient and husband has control, } 5 \text {. Wife has } \\
\text { a say in important household decisions] }\end{array}$ & $\begin{array}{l}\text { [Respondent selects picture which represents } \\
\text { first choice. Question repeated until all pic- } \\
\text { tures ordered.] }\end{array}$ \\
\hline $\begin{array}{l}\text { Coins for Financial } \\
\text { Stability vs. Respect }\end{array}$ & $\begin{array}{l}\text { Assume that these coins represent how much you value a particular characteristics } \\
\text { in your life. Distribute these } 9 \text { coins among these } 2 \text { pictures based on how important } \\
\text { these are to you. [Pictures shown for } 1 \text {. Financial stability, 2. Community respect] }\end{array}$ & $\begin{array}{l}\text { Coins for Financial Stability/ Coins for Com- } \\
\text { munity Respect }\end{array}$ \\
\hline \multicolumn{3}{|c|}{ C. Perception of Community Attitudes (Male and Female Respondents) } \\
\hline $\begin{array}{l}\text { Which Spouse Pays } \\
\text { Social Cost }\end{array}$ & $\begin{array}{l}\text { If a woman works for pay on someone elses field, do the people in your neighborhood } \\
\text { speak more badly of the wife or of the husband? }\end{array}$ & Wife/ Husband/ No Difference \\
\hline $\begin{array}{l}\text { Coins for Community } \\
\text { Thinking Badly of } \ldots\end{array}$ & $\begin{array}{l}\text { [Instructions: Think about all the people in your neighborhood. I will say a state- } \\
\text { ment now. Tell me how many people in your neighborhood will agree to this state- } \\
\text { ment using these } 10 \text { coins. In other words, if you were to talk to ten of your } \\
\text { neighbors, how many of them would agree with this statement?] }\end{array}$ & \\
\hline ...Working Woman & $\begin{array}{l}\text { Can you tell me how many people in your neighborhood would speak badly of a } \\
\text { woman who works for pay on someone elses field? }\end{array}$ & Number of Coins \\
\hline $\begin{array}{l}\text {...Working Woman's } \\
\text { Husband }\end{array}$ & $\begin{array}{l}\text { Can you tell me how many people in your neighborhood would believe that the man } \\
\text { is a bad provider if the wife is working for pay on someone elses field? }\end{array}$ & Number of Coins \\
\hline
\end{tabular}

